\title{
Secession Outside the Colonial Context: The Birth of Eritrea in Retrospect
}

\author{
${ }^{1}$ Olusesan A. Osunkoya \& ${ }^{2}$ Adeniyi S. Basiru \\ ${ }^{1}$ Tai Solarin University of Education, Ijagun, Ijebu-Ode, Nigeria \\ ${ }^{2}$ University of Lagos, Akoka-Yaba, Lagos, Nigeria \\ sesanosunkoya@gmail.com; asbash72@yahoo.com \\ DOI: https://doi.org/10.32890/jis2018.14.2
}

Received: 26 July 2018

Revised: 10 November 2018

Accepted: 5 December 2018

\begin{abstract}
In light of the recent waves of secessionist struggle and conflict in Africa, a number of debates have spurred the possibility of secession outside the colonial context. Sourcing data from documentary materials coupled with the application of historical methods of data analysis, this article reflects on Eritrea's secession from Ethiopia in 1993. The study discusses and argues that Eritrea's feat in 1993 was made possible by certain domestic and external factors that did not present themselves to earlier secessionist movements. It concludes that without those factors that made Eritrea secession possible for its re-invention, furthermore, given that the forces that propelled the 1964 Cairo Agenda are still alive and formidable, secession outside the colonial context in Africa is likely to remain a difficult endeavor.
\end{abstract}

Keywords: Secession, self-determination, Eritrea, Ethiopia, colonialism, Resolution 16.

\section{Introduction}

In the aftermath of the First World War, a new principle which later became the courted bride of minorities all over the world arrived on the international diplomatic scene. 'Selfdetermination', a nomenclature used by its promoters, proclaims the sovereign rights of the people to determine their own destinies, in states of their own, if that was what they desired (Heraclides, 1991:1). Indeed, to President Woodrow Wilson and other liberal-minded statesmen of the post-WWI era, upholding the principle of self-determination which guaranteed the democratic right to independence for ethno-national groups, within the Austro-Hungarian and Ottoman empires, would form the basis for a durable post-war world order (Whelan, 1994:108). Thus, during the inter-war period and in subsequent decades, the principle became the moral basis through which many ethno-national movements justified their demands for independence (Ajala, 1998: 47). In Africa, after the Second World War, it became the rallying ideology that the nationalists deployed, to demand secession from the colonial states. Moreover, the principle of self-determination, which gave birth to the 'UN Resolution 1514' of 1960, appeared to have triggered the first waves of secession in 
Africa, in which many hitherto colonies attained independence (see UN Doc.A/4684, 1960; Brownlie, 1989: 298-301). However, unlike many of the European countries in which the territorial boundaries of the state coincided with the national boundaries, the boundaries of political states that emerged from the colonial states in Africa were incongruent with ethnic boundaries (see Zartman, 1965; Herbst, 1992).

Consequently, secession within the states of Africa, particularly the separation of Katanga in the newly independent Congo, led to calls by various secessionist and irredentist groups for the redrawing of the inherited African state boundaries to reflect the continent's ethnic diversity (Legum, 1962; Lemarchand, 1962). However, the re - drawing of the continent's map may have propelled the custodians of the new African states to realise the potential dangers toward the status quo and insisted that the rights to sovereign statehood by ethnonational groups could not be interpreted outside the colonial framework (Jama, 2012: 30). Indeed, this position was given legal backing at the first Organization of African Unity (OAU) Summit at Addis Ababa, in 1963. In response to the crisis in Congo, African leaders supported the inviolability of national borders as one of the organization's core principles (Bamfo, 2012: 38). Thus, Article 3(6) of the OAU Charter is as follows: "respect for the sovereignty and territorial integrity of every state" (Griffiths, 1986: 213). In 1964, OAU leaders formally backed this principle at the Cairo Summit. Resolution 16 of the Cairo Summit declared that "all member states pledge themselves to respect the borders existing on their achievement of national independence in a manner that is in harmony with the principles of sovereignty and territorial integrity in the OAU Charter" (Tauval, 1967:103).

By this proclamation, the immediate post-independent African leaders appeared to have foreclosed the secession of new states outside the colonial context in the near future. Unfortunately, this did not stop secessionist threats and attempts at secession by various ethno-national groups ${ }^{1}$. In 1991, the Eritrean People's Liberation Front (EPLF) denied the principles of national border set ou in the OAU Charter when it successfully led the Eritreans, following decades of armed struggles with the authorities in Addis Ababa, to secede from Ethiopia. Therefore, a sovereign state outside the colonial context was established. This development aside from being epochal and unexpected, many observers believed that the sanctity of Resolution 16 of the Cairo Summit would have ended secession ideology throughout Africa. This raised an important question with which this article seeks to engage: what made the Eritrea's case exceptional?

Since its declaration of independence in 1991 and subsequent admission into the establishment of independent nations, following the UN-organized plebiscite, there have been many studies that have explored Eritrea's success (see Mazrui, 1993; Yohannes, 1993; Haile, 1994; Iyob, 1995; Connell, 1997; Connell, 2001; Plaut, 2002; Tronvoll, 2009; Engelbert, 2014), However, there is the need to further engage the discourse on secession in Africa. This is even more compelling with the recent secession of South Sudan from the Sudanese state as well as the rising prevalence of secessionist struggles and conflict across the continent. The rest of the article examines the conceptual framework of secession and 
historicize the struggles that prompted the independence of Eritrea. The analysis of the salient factors which contributed to the Eritrea's story outside the colonial context will be analysed. Its discussion will be further review and concluded in the last section of the article.

\section{Conceptual Framework: What is Secession?}

In spite of its popularity in international relations discourse, the concept of secession, like many of its peers, has been contested and has divergent meanings (Doyle, 2010: 1). In other words, there are varied definitions of what constitutes the phenomenon of secession in literature. Reinforcing this contention, Pavikovic \& Radan (2007:4) notes that, "there is little consensus amongst scholars on the definition of secession". Clearly evident in the foregoing is that there are no generally accepted framework for defining secession. Nevertheless, notable scholars of International Relations have embrace their views on what secession means. Crawford (1979:247) refers to it as "the creation of a state by the use or threat of force and without the consent of the former sovereign". Bartkus (1999:3), in his own contribution, conceives it as "the formal withdrawal from an established, internationally recognized state by a constituent unit to create a new state". For Kohen (2006:1), it is "the creation of a new independent state entity through the separation of part of the territory and population of an existing state". Anderson (2013:344), in his own intervention, defines secession as "the withdrawal of a territory from part of an existing state to create a new state". Pavikovic and Radan (2007:1) viewed secession as a process of withdrawal of a territory and its population from an existing state and the creation of a new state on that territory. Evidently, the common denominator in the foregoing definitions is that they all agree that secession entails creating new states out of existing ones. This observation however, do point to some divergence based on the criteria that each scholars adopts in determining what constitutes secession. For instance, while Crawford (1979), concluding from the case study conducted on Bangladesh, frames the definition of secession around the idea of forceful break-away from the host state; Bartkus (1993) and Kohen (2006) view secession as states created or formed outside the colonial context. In contradiction to the viewpoint established by Bartkus and Kohen, Anderson is of the assumption that secession is the process whereby state formation is a result of decolonization.

From the underlying definitions of secession, the concept can either be viewed in the colonial or outside the colonial contexts. Both perspectives capture how discourses on secession has been framed in Africa since the 1960s. However, it is stressed that irrespective of the divergence of views on the subject, the view that presents secession as a process, arising from decolonization and liberation struggles, has been the dominant one. Instructively, this dominant view tends to mirror the UN principle ${ }^{2}$ on colonized people which sanctioned the formation of new states only to the territories which are recognized as 'non-self-governing territories' that are separated from the host state not only ethnically but by sea or ocean (Higgins, 1994:124). Therefore, in this article, secession is defined in the colonial context. 
This would suggest a formal process by which a territory and its inhabitants exits from the colonial state with the aim of establishing themselves as a sovereign state. Secession, outside the colonial framework, in which a territory that has attained a sovereign status that is subsequently separated further to other territories, is not acceptable in Africa. Accordingly, based upon the definition used in this article; Could Eritrea's exit from Ethiopia be defined as an act of secession? We will come to this shortly but before then, it is apposite to put the trajectories of the struggles that prompted the independence of Eritrea in 1993.

\section{From Re-colonization to Freedom: Navigating Eritrea's Journey towards an "Impossible" Independence}

The decades old struggle that culminated in the formal divorce of Eritrea from Ethiopia on May 24, 1993 is rooted in the history of alienation and marginalization dating back to the arrival of Western colonialism during the turn of the $19^{\text {th }}$ century. Before this era, the territory, now designated as Eritrea, had for centuries been peopled by various tribes at different levels of socio-political development. Although, they differed in terms of belief systems, culture, occupation and system of government, they all experienced centuries of oppression from the Arabs, Ottoman Turks and the Egyptians (Mussie, 2011). None of these external forces succeeded in creating a modern centralized state in the area. It was not until January 1, 1890, following the conquest of the various indigenous communities by the Italian forces and the subsequent naming of the territory "Erythraeum Mare", that the process of modern state formation commenced (Fegley, 1995: xv). Like the various European colonies in Africa, driven by the logic of civilizing mission, the Italian rulers of the new possession, although exploited and alienated the people, brought modernization in the areas of medical service, agriculture, banking, manufacturing, light industry, road and railway system. Troco (2014), in a study on Eritrea notes that, "Italian modernization project led to the modernization of Massawa as well as the expansion of Asmara, the capital city" (p.8). Unfortunately, Italy did not provide the opportunity to prepare the colony of Eritrea for independence. Its rule over the territory ended in 1941, following the defeat of its forces by the British-led Allied forces during the Second World War (Jacquin, 2006:140).

Following the war, Italy formally renounced sovereignty over Eritrea, in fulfilling the terms of the Peace Treaty, signed with the victorious powers ${ }^{3}$. However, the inability of the quartet comprising of the United States, Soviet Union, France and Britain ${ }^{4}$ to agree on the future of Eritrea paved the way for the United Nations to take the lead (Sherman, 1980: 21). To this end, the organization set up a five-nation committee, made up of Norway, Burma, South Africa, Guatemala and Pakistan, to collect and document the views of the Eritrean people as well as to look into Ethiopia's claims that Eritrea historically belonged to Ethiopia (Troco, 2014: 26). The Committee was divided in its recommendations. While the representatives from Pakistan and Guatemala recommended that Eritrea be made a sovereign state, their counterparts from Burma, Norway and South Africa recommended that there should be a close association between Eritrea and Ethiopia. The latter's position was later accepted at 
the UN General Assembly on December 2, 1950 when the organization adopted a resolution to federate Eritrea with imperial Ethiopia (Okbazghi, 1997: 129). Putting the UN Resolution in context, Fegley (1995: xxxviii) notes:

\begin{abstract}
The UN General Assembly resolution, adopted by a vote of forty-seven to ten, provided that Eritrea should be linked to the Ethiopian Empire through a loose federal structure under the sovereignty of the Ethiopian emperor but with a form of internal self-government. The federal government, in the same way as the existing imperial government, was to control foreign and defense affairs, foreign and interstate commerce, transport and finance. Control over domestic affairs (including police, local administration, and local taxation to meet its own budget) was to be exercised by an elected Eritrean assembly on parliamentary model. The Eritrean state was to have its own administrative and judicial structures and a flag.
\end{abstract}

In complying with the UN resolution, the Ethiopian Emperor, Haile Selassie, on September 11, 1952 ratified Eritrea's constitution, thus forming the Ethio-Eritrean Federation (Iyob, 1995: 64). By this agreement, Eritrea's territory and its population, albeit under a federal contract, came under the sovereignty of the Ethiopian state. Not long after the ratification of the Charter for the unification of Ethiopia and Eritrea, Emperor Haile Selassie began to repudiate the agreement. Thus, on September 30, 1952, he issued a decree declaring the federal Ethiopian court as the country's final Court of Appeal, thus violating the autonomy of Eritrean courts as enshrined in Articles 85 and 90 of the Eritrean Constitution (Troco, 2014: 27). This was followed by a coordinated process of harassment and intimidation of pro-Eritrean elements and organization. For instance, in July 1953, Selassie's government issued a decree requiring all Eritrean males in the urban areas to carry their identity cards at all times. Some of the actions taken by the Emperor to nullify Eritrea's federal autonomy, as provided in the UN resolution, included the declaration of Amharic language as the official language of Eritrea in 1956, thus relegating Tigre and Tigrinya languages; the passing of a bill that discarded the Eritrean flag in 1958; the replacement of Eritrean laws by the Ethiopian penal code in 1959; and the manipulation and intimidation of the elected Eritrean Assembly to change its name from the Eritrean Government to Eritrean Administration that took place in May 1960 despite protests from students and workers.

On November 14 1962, Eritrean autonomy was officially buried when Eritrea became Ethiopia's fourteenth province, following the abrogation of Eritrea's autonomous status by the Eritrean representatives, albeit, under intense pressure and intimidation (Iyob, 1995:95). These events eventually culminated to a series of protests and strikes which were often violently crushed by the Ethiopian security forces (Killion, 1997:12). The continued use of violence by the authorities in Addis Ababa to deal with the rising discontent in the province of Eritrea gave impetus for the formation of a liberation movement, that started with the Eritrean Liberation Movement (ELM), established in Port Sudan, in November 1958 (Jacquin, 2006: 155). Predating the abrogation of the federal agreement, ELM initially 
sought to mobilize support within and outside Eritrea against the growing erosion of the federation, however changed its goal to liberation when the authorities in Addis Ababa dissolved the Ethio-Eritrean Federation (Markakis, 1987: 55; Negash, 1997: 148). ELM was later joined in its struggle for independence by the Eritrean Liberation Front (ELF) which unlike the ELM, resorted to violent armed struggles in their quest to liberate the people.

It is instructive to note that the two secessionist movements rather than working together embarked on war of attrition which led to the demise of ELM in 1970. As Troco (2014:31) remarks, "the appearance of the ELF signaled the demise of the ELM as the movement had to fight a two front war against the Ethiopian security forces and a new antagonistic front". Given its commitment to armed struggles, throughout the 1960s, the ELF launched a number of guerrilla attacks against government targets in which several senior officers, including the Commanding General of Ethiopia's Second Division, were killed in ambushes in Asmara, Keren and Agordat (Lobban, 1976: 340; Halliday, 1971: 62). Although the Ethiopian security forces retaliated by killing thousands of Eritreans and forced thousands to take refuge in Sudan, this only served to mobilize Eritrea's population against the government of Ethiopia (Jacquin, 2006: 160).

Moreover, as the imperative of reforming the Front's structure as well as relocating its command headquarters from Cairo to a base inside Eritrea gathered momentum, dissension occurred. As a result, two breakaway groups, the ELF-PLF and the Tripartite Union, emerged to challenge the EPF. In 1972, the Tripartite Union led by Isaias Aferworki, who will later become the first President of an independent Eritrea, was renamed the Eritrean People's Liberation Front (de Waal, 1991: 42) Unfortunately, rather than work together, the various fronts fought one another. According to Troco (2014:34), the first civil war in Ethiopia was not between the fronts and the Ethiopian military but rather between the EPF and EPLF. The war, however, ended in 1974 through the formation of a united front against the Derg, a committee of 128 junior military officers led by Mariam Hale Mengistu which had overthrown the government of Haile Selassie on $12^{\text {th }}$ September, 1974. As Jacquin (2006:164) notes, "between 1975 and 1976, following the agreement to set aside their differences, the ELF and EPLF joined forces and succeeded in overrunning about $90 \%$ of the entire Eritrean territory except Asmara, Massawa and the small town of Barentu in the west".

However, it is important to note that the victory coincided with the Somalian troops' invasion of the Ogaden region which compelled the regime in Addis Ababa to direct its military resources towards a more formidable enemy. The victory between the fronts was short-lived as the Ethiopian forces, having flushed out the Somalian forces from the Ethiopian territory gained Soviet military support, after the Mengistu regime had separated with Washington in 1978. The joint alliance launched a major operation to re-capture the territories earlier occupied by ELF/EPLF (Sherman, 1980: 93). Though the Ethiopian forces re-captured some of the territories earlier lost to the ELF/EPLF guerilla forces, the war ended 
in a strategic stalemate which lasted until 1984 (Troco,2014: 34). Between 1980 and 1981, another intra-Eritrea war broke out between the ELF and EPLF that ended with a victory for the EPLF (Markakis, 1987: 67). Henceforth, EPLF assumed the role of sole liberator of Eritrea, mobilizing the masses and building up their military arsenal to be deployed by its forces to break the military stalemate (Thomas, 2012: 12).

After many failed attempts by the Ethiopian army to break the stalemate, EPFL moved into the offensive which paid off with a decisive victory at the Battle of Afabet. This decisive victory further boosted the morale of the EPFL forces and with the collaboration of other rebel groups, notably the Tigray People's Liberation Front (TPLF), the Oromo Liberation Front (OLF) and the Ethiopian People Republic Democratic Front (EPRDF) which had joined the resistance against the Mengistu's regime, the EPLF captured Massawa and other major towns of Eritrea in February 1990. On May 21, 1991, Mengistu fled to Zimbabwe and four days later, the Ethiopian forces surrendered Asmara to EPLF without any resistance. On 28 May, 1991, EPRDF captured Addis Ababa that led to a regime change in Ethiopia. The following day, Isaias Aferworki, the leader of EPLF, having agreed to postpone for two years a referendum on independence, declared Eritrea's de facto independence (Thomas, 2012:12). In July 1991, a conference on peace and democracy, organized by EPRDF was held in Addis Ababa. The conference did not only formally recognize the right of the Eritrean people to determine their political future by an internationally supervised referendum but also decreed that Eritrea had not only seceded but also recovered its independence.

Two years later, a UN sponsored referendum was organized, and 99.8 percent of Eritreans voted for independence (Iyob, 1995:36). On May 24, 1993, Eritrea was officially admitted into the community of states. With the support of the United States and other major powers, OAU eventually recognized Eritrea as the $53^{\text {rd }}$ state in Africa (Paquin, 2010:141). As Coggins (2011:449) observes, "when a Great Power confers legitimacy upon a secessionist movement/state, its decision initiates a cascade of legitimacy throughout the remaining members of the system".

It is clear from the foregoing, that Eritrea's decades-long struggle to divorce from Ethiopia had its foundation laid in the error of the international community after World War Two. The decision to deny Eritreans' quest for an independent statehood as a case of decolonization and instead, federated it with an independent Ethiopia, led to the establishment of another colony rather than an autonomous entity. Subsequently, the Eritreans perception of the eventual recolonization by Imperial Ethiopia, despite their ethnic differences, led to discontent and grief. This in effect, snowballed into agitation and eventually conflict that led to Eritrea's secession in 1993. In hindsight, considering the factors that would trigger a secession, Wood (1981:121) writes, “a group's perceptions or anticipation of denial of its 'rightful' share (of benefits); a decline in the legitimacy or politically integrative capacity of the central governments; and the perception or anticipation of threat to the group's identity and security". 


\section{Defying Resolution 16: Eritrea, Ethiopia and the International Community}

The independence of Eritrea in 1993 against all odds, came as a surprise to many observers. Given the number of factors that had prevented various secessionist attempts in Katanga, Biafra, and Casamance, the fate of would be secessionist states was indeed settled at Cairo with the declaration of Resolution 16. The stance taken by the Organization of African States in all these secessionist attempts and conflicts, was that they were in violation of the territorial integrity of a member state as stipulated in Article 3(6) of the OAU Charter and the principle of uti possedetis ${ }^{5}$ declared at the Cairo Summit. This viewpoint essentially became the yardstick for settling territorial disputes among member states of the OAU. With reference to the case of Burkina Faso and Mali, the International Court of Justice (ICJ) observed that, "the essential requirement of stability in order to survive, to develop and gradually to consolidate their independence in all fields, has induced African states to judiciously consent to the respecting of colonial frontiers, and to take account of it in the interpretation of the principle of self-determination of peoples ${ }^{6}$. Therefore, the foregoing infer that the politico-legal environment of Africa is not favourable to peoples' quest for self-determination outside the colonial context. In other words, peoples' self-determination claims cannot be interpreted as a right to secede from the existing state system (see Haile 1996) ${ }^{7}$. Hence, what makes the case of Eritrea unique?

The hypothesis is that Eritrea's success was the result of a combination of many internal and external factors which did not present themselves to earlier movements. The first, is the domestic factor that points to the military defeat inflicted on the Ethiopian armed forces by the EPLF. The rational is that if the Ethiopian armed forces, together with the military involvement of TPLF and OLF had not been defeated, the opportunity for EPLF to declare independence would not have presented itself (Troco, 2014:41). Futhermore, coupled with the Ethiopian military defeat thesis is the fact that EPLF adopted a number of measures which were not implemented by previous secessionist struggles. Some of these included: adhering maximally to Maoist strategy of prolonged and protracted warfare, winning the legitimacy of the population by embarking on reforms in territories under its control, making effective use of captured arms and ammunition from Ethiopian forces, and forming formidable alliances with other liberation movements (Thomas, 2012; Sherman, 1980; Keller, 2007).

Another internal factor that would have accounted for the success of Eritrea was the extreme centrist policies of Mengistu. Upon consolidating power, the head of the Derg regime, Mengistu, in pursuit of his policy of "Ethiopia first", clamped down on ethnonationalist organizations (Troco, 2014:40). Specifically, thousands of Eritreans, Somalis and Oromians in his "Red Terror" operation were imprisoned, tortured and executed. The policy of marginalization by the regime of Mengistu offered opportunities to nurture antistate feelings which provided fertile ground for the recruitment of fighters. Ylonen (2013: 131) stated that; "the gross violation of groups' rights and other policies of alienation and exclusion by the regime of Mengistu gave impetus for the emergence of EPRDF which co- 
ordinated the final push that led to the collapse of the Mengistu regime and the eventual independence of Eritrea".

Another factor that supported Eritrea's success in its struggle, was the strong legal and historical foundation upon which the Eritrea's claim to independence was built (Thomas, 2011:25). During the conflict, Ethiopian authorities insisted that Eritrea was Ethiopia's 14 ${ }^{\text {th }}$ province based on the historical fact that Eritrea was part of the ancient Ethiopian empire. On the contrary, the Eritrean leaders argued that the Italian colonial rule had severed Eritrea ties, culturally and socially, from whatever historical ties that had existed (Troco, 2014:36). Anchoring their argument on the Addis Ababa Treaty of 1896, which affirmed Italian rule over an expanded Eritrea, the Eritrean leaders claimed that their territory had long existed as a separate entity, detached from Ethiopia. It was on the basis of this historical fact that the Eritreans justified their struggles, not by secession from an existing state but that of decolonization against the re-colonization of an African colonizer (Thomas, 2012: 32). Considering the extant of international legal norms which were against state mutation for fear of domino effect, the framing of the Eritrean struggle as an act of decolonization morally strengthen the Eritrean case diplomatically and helped Eritreans avoid key errors made by previous secessionist attempts in Africa.

The changing international environment is another major factor responsible for the success of the Eritrean secession outside the colonial context. Specifically, at the end of the Cold War in 1999, that transformed the old rigid east-west framework through which international diplomacy has, for four decades, been framed (Troco, 2014: 37). For instance, while the Cold War lasted, international politics in Africa was structured within the eastwest framework. This may have made it easy for African leaders to play one super power against another (Schraeder, 1992:165). As a matter of fact, it was this arrangement that made it possible for Mengistu to get \$500 million worth of arms from the Soviet Union in 1977 following the regime's parting of way with the country's erstwhile benefactor, the United States (Sherman, 1980: 90).

The conditions eventually changed at the end of the Cold War. With regard to the Soviet Union, Mikhail Gorbachev's policy of democratic openness that was introduced on his assumption of power in 1985, allowed the former members of the eastern bloc to exercise their right of self-determination. This policy provided necessary armoury for the Eritrean secessionist movement to further press for their case. It may have been on the basis of this policy that Gorbachev canceled the Soviet-Ethiopia arms deal in 1990. Moreover, the eventual balkanization of the Soviet Union into many states as well as the breaking up of Yugoslavia and Czechoslovakia further emboldened the Eritreans. As Iyob (1995:138) avers, "the demand of the Eritrean people for self-determination was no longer seen as an isolated case viewed as a dangerous precedent, but one of many cases".

Furthermore, the changing international climate may also have made the United States which since the 1950s, oppose Eritrean independence but eventually reappraise its position on the 
Eritrean question. In the absence of other major contender in the horn of Africa, ending the civil war in Ethiopia to ensure stability in the region was of vital importance to Washington. It is in their point of view, that supporting the secession of Eritrea that has been pursuing its continuous war - driven policies could potentially harm US interest within the region. In retrospect, Paquin (2010:141) posits that, "a denial of Eritrea's right to secede may have caused war to resume in Ethiopia". Therefore, it may be plausible to argue that Eritrea's secession from Ethiopia in 1993 were made possible by certain domestic and external factors that did not present themselves to earlier secessionist movements. It is the totality of these factors that made the secession of Eritrea outside the colonial context possible. Interestingly, except for South Sudan in 2011, whereby its independence was facilitated by the international community, no other secessionist state has emerged in Africa.

\section{Conclusion}

Despite numerous attempts by various secessionist groups, since the Katanga episode of 1960, to redraw Africa's political map to reflect the ethno-national complexities of the continent, secession before 1993 was a rarity. This article examined secession outside the colonial context in Africa and reflected on Eritrean success story. From the review of extant literature, it is revealed that Eritrea's success was made possible by a legion of intermestic factors that did not present themselves to previous and later secessionist movements in Africa. Some of these include: the anomalous history between Ethiopia and Eritrea, policy of social embededness adopted by EPPF, post-Cold War re-alignment of international forces, weakness in the Ethiopian national economy and US rapprochement with EPPF. Based on these perspectives, the article argues and concludes that except for those factors that made Eritrea's secession possible for its re-invention, secession outside the colonial framework in Africa, given the extant international legal order that do not support state balkanization coupled with the fact that contemporary African statesmen are likely to abandon the agenda set forth by their forebears at Cairo in 1964, will likely remain a difficult endeavour. This is still in accordance with the fact that the forces and conditions that drove the 1964 Cairo agenda are still alive and are as formidable as ever.

\section{Notes}

1 Some of the prominent secessionist attempts include: Igbo People (Biafrans) versus Nigeria, Kantangese versus Zaire, Cunne people versus Cameroon, Cabindas versus Angola, e.t.c.

2 Declaration on the Granting of Independence to Colonial Countries and Peoples, GA Res. 1514 (XV) (1960)

3 The victorious powers after the Second World War were the United States, Britain, Soviet Union and France.

4 While France favoured the continuation of Italian rule over Eritrea, Britain proposed that the territory be partitioned between Sudan and Ethiopia. While the Soviet Union supported the idea of individual trusteeship for Eritrea, the United States recommended a collective UN trusteeship for ten years followed by independence. 
5 The principle of uti possedetis posits that newly decolonized states should inherit colonial administrative borders held at the time of independence.

6 See Burkina Faso v. Mali, ICJ Rep. (1986) 567

7 In a few countries, external right to self-determination has been formally institutionalized. For example, in the defunct constitution of former Soviet Union, the Union republic had the right to secede. Czechoslovakia dissolved into two independent states in a peaceful manner. The Canadian constitution provides window for Quebec and other provinces to secede from Canada if they so wish.

\section{References}

Ajala, A. (1998) Decolonization and liberation in Africa. In G. Obiozor \& A. Ajala (Eds.), Africa and the UN system: The first fifty years. Lagos: Nigerian Institute of International Affairs.

Anderson, G. (2013) Secession in International Law and Relations: What are we talking about? Retrieved from http://digitalcommons.lmu.edu/ilr/vol35/iss3/1, 344

Bamfo, N. (2012). The menace of secession in Africa and why governments should care: The disparate cases of Katanga, Biafra, South Sudan, and Azawad. Global Journal of Human Social Science: Sociology, Economics \& Political Science, 12, 10.

Bartkus, V. O. (1999). The dynamics of secession. Cambridge: Cambridge University Press. Brownlie, I. (1971). Basic documents on African affairs. Oxford: Clarendon Press.

Brownlie, I. (1989). Basic documents in International Law. Oxford: Clarendon Press, Oxford.

Coggins, B. (2011) Friends in high places: International politics and the emergence of states from secessionism. International Organization, 65,1.

Connell, D. (1997). Inside the EPLF: The origins of the people's party and its role in the Liberation of Eritrea. Review of African Political Economy, 28, 89.

Crawford, J. (1979). The creation of states in International Law. Oxford: Clarendon Press.

Crowley, D. (1963). Politics and tribalism in the Katanga. The Western Political Quarterly, $16,1$.

de Waal, A. (1991). Evil days: 30 years of war and famine in Ethiopia. (New York: Human Rights Watch)

Doyle, D. H (2010). Secession as an International phenomenon: From America's civil to contemporary separatist movements. Georgia: University of Georgia Press.

Engelbert, P. (2014) Separatism in Africa. Routledge Handbook of African Security. (ed.) J. Hentz. London: Routledge.

Fegley, R. (1995). Eritrea. Colorado: Clio Press.

Griffiths, I. (1986). The scramble for Africa: Inherited political boundaries. The Geographical Journal, 152, 2.

Haile, M. (1994). Legality of secessions: The case of Eritrea. Emroy International Law Review, 8 . 
Haile, M. (1996). The new Ethiopian constitution: Its impact upon unity, human rights and development. Suffolk Transnational Law Review, 20.

Halliday, F. (1971). The fighting in Eritrea. New Left Review, lxviii, May-June.

Heraclides, A. (1991). The self-determination of minorities in international politics. London: Frank Cass \& Company Limited.

Herbst, J. (1992). Challenges to Africa's boundaries in the new world order. Journal of International Affairs, 46, 1, Summer.

Higgins, R. (1994). Problems and process: International law and how we use it. Oxford: Clarendon Press.

Iyob, R. (1995). The Eritrean struggle for independence: Domination, resistance, nationalism 1941-1993. Cambridge: Cambridge University Press.

Jacquin, D. (2006). Nationalism and secession in the Horn of Africa: A critique of the ethnic interpretation (Unpublished doctoral dissertation). London: London School of Economics and Political Science, University of London.

Jama, H. (2012). Self-determination in Africa: A case study of Somaliland(1991-2011).M.A Nairobi: University of Nairobi.

Keller, E. (2007). Secessionism in Africa. The Journal of African Policies, 13, 1.

Killion, T. (1996). The Eritrean economy in historical perspective. Eritrean Studies Review, 1,1 .

Killion, T. (1997). Eritrean workers' organization and early nationalist mobilization: 19481958. Eritrean Studies Review, 2, 1.

Kohen M. G. (2006). Secession: International law perspectives. Cambridge: Cambridge University Press.

Legum, C. (1962). The dangers of independence. Transitions, 6/7.

Lemarchand, R. (1962). The limits of self- determination: The case of the Katanga secession. The American Political Science Review, 56, 2.

Lobban, R. (1976). The Eritrean war: Issues and implications. Canadian Journal of African Studies, 10, 2.

Markakis, J. (1987). The nationalist revolution in Eritrea. The Journal of Modern African Studies, 26, 1.

Mazrui, A. (1993). The bondage of boundaries: Why Africa's map will be redrawn. The Economist, 328.

Mussie, T. G. (2011) Eritrea. California: Greenwood Publishing Group.

Negash, T. (1997). Eritrea and Ethiopia: The federal experience. Uppsala: Nordiska Afrikainstitutet.

Okbazghi, Y. (1997). The United States and the horn of Africa: An analytical study of pattern and process. Boulder, $\mathrm{CO}$ : Westview Press.

Paquin, J. (2010). A stability-seeking power: U.S. foreign policy and secessionist conflicts. Quebec: McGill-Queens University Press.

Pateman, R. (1990). The Eritrean war. Armed Forces and Society. 17, 1 Fall.

Pavković, A. \& Radan, P. (2007). Creating new states: Theory and practice of secession. Hampshire: Ashgate Publishing. 
Plaut, M. (2002). The birth of the Eritrean reform movement. Review of African Political Economy, 91.

Plaut, M. (2002). The Eritrean Struggle for Independence: Domination, resistance, nationalism 1941-1993. Cambridge: Cambridge University Press.

Schraeder, P. J. (1992). The horn of Africa: US Foreign Policy in an Altered Cold War Environment. Middle East Journal, 46, 4.

Sherman, R. (1980). Eritrea: The unfinished revolution. New York: Praeger.

Tauval, S. (1967). The organization of African unity and African Borders. International Organizations, 21.

Thomas, C. G. (2011). The aberration of Eritrean secession, 1961-1993 (Master's thesis). Austin: Faculty of the Graduate School, The University of Texas, USA.

Thomas, P. (2012) The road to Afabet: The EPLF, protracted warfare, and the liberation of Eritrea. Acta of the XXXVII International Congress of Military History, Decolonization, Colonial, and Independence Wars from the 18th Century to the Present (ed.). Brazilian Army Command. Rio de Janeiro: ECEME Press.

Troco, A. (2014). Determinants of successful secessions in post-colonial Africa: Analyzing the Cases of Eritrea and South Sudan. (master's thesis). Pietermaritzburg: School of Social Sciences, University of KwaZulu-Natal, South Africa.

Tronvoll, K. (2009). The lasting struggle for freedom in Eritrea: Human rights and political development, 1991-2009. Oslo: Oslo Centre for Human Rights.

Whelan I. (1994). Wilsonian self-determination and the Versailles settlement. International and Comparative Law Quarterly, 43.

Wood, J. R. (1981). Secession: A comparative analytical framework. Canadian Journal of Political Science, 14,1.

Ylonen, A. (2013) The state and the southern problem in Sudan: Marginalization, selfdetermination and secessionism. The Bondage of boundaries and identity politics in postcolonial Africa: The Northern Problem and Ethno-Futures (Eds.), S. NdlovuGatsheni \& B. Mhlanga. Pretoria: Africa Institute of South Africa.

Yohannes, Y. (1993). Eritrea: A country in transition. Review of African Political Economy, 57.

Zartman, W. (1965). The politics of boundaries in north and west Africa. Journal of Modem African Studies, 3, 2. 